Nr 2(65), 2020, s. 273-286

https://doi.org/10.12797/Politeja.17.2020.65.19

\author{
Agnieszka GĘBCZYŃSKA-JANOWICZ (D) \\ Politechnika Gdańska \\ agnjanow1@pg.edu.pl
}

\author{
Anna AWTUCH \\ Politechnika Gdańska \\ anna.awtuch@gmail.com
}

\title{
ARCHITEKTURA POMNIKÓW POŚWIĘCONYCH OFIAROM ATAKÓW TERRORYSTYCZNYCH JAKO KONTYNUACJA REALIZACJI KOMEMORATYWNYCH KSZTAŁTOWANYCH W POSTPAMIĘCI
}

ABSTRACT Architecture of Memorials Dedicated to the Victims of Terrorist Attacks as a Continuation of Commemorative Structures Created within Post-memory Having the rich art of commemorating events of the Second World War as a key reference, this article will try to show how contemporary architectural interventions in public space make attempts to respond to the social need of dealing with traumatic events and formulating a new attitude towards threatened places. The point of reference for our reflections will be the events affecting contemporary city in the $21^{\text {th }}$ century associated with terrorist attacks. In order to determine types of architectural narratives about traumatic events developed in urban space, some memorial places in Europe and the USA will be analysed (e.g. Atocha station in Madrid, 9/11 Memorial in New York, Oklahoma City Bombing Memorial). Referring to examples of memorials and monuments, we will look at contemporary tendencies in designing commemorative architecture and how architecture reflects and supports the social and individual process of trauma recovery.

Keywords: architecture, urban landscape, memorial, post-memory, terrorism

Słowa kluczowe: architektura, krajobraz miejski, pomnik, postpamięć, terroryzm 


\section{POMNIK W MIEŚCIE}

Architektura przestrzeni miejskiej to złożona struktura wykreowana wysiłkiem wielu pokoleń. Tworzone na przestrzeni dziejów budowlane artefakty reprezentują przeszłość miasta w teraźniejszości. Z analiz powstających przez kolejne dekady nawarstwień architektonicznych można wywnioskować zarówno historię ich użytkowników, jak i kontekst kulturowy, w którym oni funkcjonowali. Podobnie jak w literackim palimpseście, fizycznie zorganizowaną przez człowieka przestrzeń można odczytywać i interpretować ${ }^{1}$ Krajobraz miasta nazywany jest w związku z tym często scenografią historycznie nagromadzonych elementów architektury, z której można czytać przeszłość miasta, jak ze słojów drzewa ${ }^{2}$. W tym nawarstwieniu znaczeń ważną rolę w przestrzeni publicznej odgrywa strefa komemoratywna ukształtowana przez budowle pełniące funkcję nośników pamięci zbiorowej. Tablice z inskrypcjami, proste elementy rzeźbiarskie, monumentalne pomniki, wielkoprzestrzenne założenia pomnikowe, budynki muzealne powstają po to, by reprezentować postawę mieszkańców wobec przeszłości, stanowiącą istotny budulec ich kulturowej tożsamości. Uformowane jako pomniki o różnej formule artystycznej i strukturze budowlanej, wizualizują w przestrzeni publicznej oficjalny nurt oceny przeszłości i stanowią signum temporis, świadcząc o wartościach społecznych, politycznych, państwowych i ogólnoludzkich epoki, w której owe artefakty powstały.

Szata komemoratywna współczesnego miasta w dużym stopniu odwołuje się do historii szeregu dramatycznych wydarzeń związanych z przebiegiem dwóch wojen światowych. Pomimo upływających dekad pamięć o stratach w ludności, zniszczonym dorobku materialnym i kulturalnym zapisywana jest w krajobrazie miast nieprzerwanie do dnia dzisiejszego. Sieci punktów połączonych wspólnym kontekstem historycznym tworzą świadectwo przeszłości dla mieszkańców oraz opowieść dla przyjezdnych. Historia przeobrażeń krajobrazów memorialnych takich miast, jak Warszawa czy Berlin, wskazuje, że sztuka pomnikowa nie tylko spełnia funkcje upamiętniające, ale stanowi asumpt do refleksji nad wpływem przeszłości na rozwój kulturalny mieszkańców. Analiza dziejów poszczególnych pomników - od momentu ich fundacji, poprzez proces powstawania koncepcji, umiejscowienie, nadanie nazwy, aż do czasu funkcjonowania i wpisywania się w ikonosferę miasta - przynosi wiele danych przydatnych w badaniach naukowych o charakterze interdyscyplinarnym ${ }^{4}$.

Współczesne miasta, szczególnie te na kontynencie europejskim i amerykańskim, coraz częściej eksponują w przestrzeni publicznej sztukę pomnikową poświęconą aktualnym wydarzeniom rozgrywającym się na ich obszarach. Instalacje artystyczne

\footnotetext{
A. Huyssen, Present pasts: Urban palimpsests and the politics of memory, Stanford 2003.

M. Golka, Imiona wielokulturowości, Warszawa 2010, s. 142.

I. Grzesiuk-Olszewska, Polska rzeźba pomnikowa w latach 1945-1995, Warszawa 1995, s. 12.

A. Gębczyńska-Janowicz, Wspótczesne miejskie krajobrazy pamięci o II wojnie światowej na przyktadzie Warszawy i Berlina, „Borussia. Kultura. Historia. Literatura” 2011, nr 50, s. 259-274.
} 
stanowią krytyczną interpretację bieżącej sytuacji społecznej. Odnoszą się m.in. do zagrożeń będących największymi bolączkami teraźniejszości.

W XXI wieku do najistotniejszych wyzwań nękających współczesne miasta należą ataki terrorystyczne. Metropolie stanowią najczęstszy cel aktów terroru ze względu na ich globalne funkcjonowanie i symboliczne znaczenie w gospodarce oraz polityce ${ }^{5}$. Po każdym wybuchu bombowym, strzelaninie, samobójczym zamachu społeczeństwo zostaje naznaczone traumą obniżającą zaufanie do bezpieczeństwa, jakie może zapewnić nowoczesna cywilizacja, a tym samym zmniejszającą komfort użytkowania przestrzeni publicznej. Mieszkańcy zaatakowanej przestrzeni mają potrzebę wizualizacji żałoby w miejscach, w których doszło do tragedii. W krótkim czasie po wydarzeniu, od roku do pięciu lat, powstaje instalacja komemoratywna oddająca hołd ofiarom ataku terrorystycznego oraz upamiętniająca wydarzenie dla kolejnych pokoleń.

Niniejszy artykuł przedstawia charakterystyczne cechy sztuki pomnikowej poświęconej stratom w wyniku ataków terrorystycznych, do których doszło w ostatnich trzech dekadach w Europie i Stanach Zjednoczonych. Zawiera porównanie środków artystycznych wykorzystywanych w instalacjach komemoratywnych poświęconych tej tematyce z tymi, które zostały wypracowane dla struktur upamiętniających wydarzenia drugiej wojny światowej.

\section{WPŁYW ZJAWISKA POSTPAMIĘCI NA PROCES REDEFINICJI POMNIKA}

Tradycyjne intencje prowadzące do erekcji pomnika przez stulecia koncentrowały się wokół materii oddawania czci wielkim wodzom lub ich zwycięstwom. Formalna redefinicja tej postawy nastąiła wraz z doświadczeniami dwóch wojen światowych, które zachwiały cywilizacją w XX wieku. Artefakty upamiętniające zaczęto poświęcać reprezentacji strat, do których prowadzą działania wojenne. Pomniki nie oddawały już tylko hołdu bohaterom, ale wizualizowały także żałobę oraz stanowiły przestrogę dla przyszłych pokoleń.

Do szeregu transformacji rozszerzających funkcję pomnika $\mathrm{w}$ dużym stopniu przyczyniło się pokolenie urodzone po drugiej wojnie światowej. Potomkowie bezpośrednich świadków traumatycznych wydarzeń podjęli się upubliczniania wiedzy o wojennych doświadczeniach krewnych. W oparciu o ten impuls pokolenie znające wydarzenia, o których chciało się wypowiadać, tylko z ustnych przekazów lub dokumentów historycznych, utworzyło specyficzny nurt kultury pamięci, który przełożył się na liczne dzieła literackie oraz reprezentacje w sztukach plastycznych. Zjawisko to Marianne Hirsch nazwała postpamięcią (ang. postmemory) ${ }^{6}$. W jej interpretacji postpamięć różni się pod względem socjologicznym od pamięci kulturowej dystansem

A. Jasiński, Architektura w czasach terroryzmu: Miasto - przestrzeń publiczna - budynek, Warszawa 2013, s. 46.

6 M. Hirsch, Family Frames: Photography, Narrative, and Postmemory, Cambridge 1997. 
wynikającym ze zmiany pokolenia, a od historii jako dziedziny naukowej faktem indywidualnego doświadczenia wydarzeń. Przedrostek „post-” podkreśla późniejsze etapy przepracowania traumy wychodzące daleko poza pokolenie świadków związanych z wydarzeniem. Pamięć potomków generacji, która przeżyła zbiorową traumę, oparta jest w znaczącym stopniu na empatycznym odtwarzaniu doświadczenia wcześniejszego pokolenia, niemniej jest to wyrazista forma pamięci ze względu na silne powiązanie ze źródłem wspomnień?

Postpamięciowa interpretacja przeszłości bezpośrednio wpłynęła na formalne transformacje sztuki pomnikowej. Symboliczna redefinicja pomnika, do której doszło w drugiej połowie XX wieku przysłużyła się popularyzacji sztuki komemoratywnej i powstaniu innowacyjnych rozwiązań artystycznych jej służących. Proces przepracowania danych historycznych przyczynił się do wielozakresowych przeobrażeń pomnika zarówno pod względem artystycznym, jak i znaczeniowym ${ }^{8}$. Odtąd pomnik funkcjonujący pomiędzy sztuką publiczną a polityką historyczną odzwierciedla zarówno rewolucje estetyczne i polityczne, jak i cywilizacyjne wstrząsy oraz związane z nimi konflikty, a także kompromisy. Intencjonalnie stanowi impuls do refleksji nad szerszym zakresem wartości powiązanych z przeszłością. Transformacja pomnika jako fizycznego nośnika pamięci zbiorowej przebiegała wielokierunkowo: od heroicznych, realistycznych, symbolicznych ikon, które sławiły narodowe ideały i triumfy, do antyheroistycznych, a często i ironicznych instalacji artystycznych, które reprezentowały narodową ambiwalencję i niepewność późnego postmodernizmu?

Dla potrzeb niniejszego artykułu zostało przyjęte określenie pomnika postpamięci. Oznacza ono dzieło utworzone na przełomie XX i XXI wieku przez artystów wywodzących się z pokolenia zainspirowanego losami swoich bliskich żyjących w czasach wojennej pożogi. Przy doborze środków oddziaływania stosowane są w tym przypadku rozwiązania artystyczne będące w opozycji do klasycznej formuły monumentalnego pomnika. Proces przepracowywania traumy po dramatycznych wydarzeniach drugiej wojny światowej przeprowadzony jest przy jednoczesnej obserwacji pamięci na tle współczesnej kondycji społecznej. Pomniki kreowane w tym nurcie, pod względem przyjętych parametrów fizycznych organizacji przestrzeni, kontynuują architekturę obiektów upamiętniających wykorzystywanych w sztuce pomnikowej tworzonej jako bezpośrednie reakcje na doświadczenia wojenne.

A. Mach, Poetyka postpamięci i etyka świadkowania w badaniach Marianne Hirsch, „Humanistyka XXI Wieku” 2010, nr 1, s. 105-116.

8 A. Gębczyńska-Janowicz, Polskie zatożenia pomnikowe. Rola architektury w tworzeniu miejsc pamięci od potowy XX wieku, Warszawa 2010.

9 J.E. Young, Memory and Counter-Memory, „Harvard Design Magazine” 1999, nr 9, s. 1-10. 


\section{ELEMENTY KOMPOZYCJI PRZESTRZENNEJ ŁĄCZĄCE REALIZACJE KOMEMORATYWNE REALIZOWANE W NURCIE POSTPAMIĘCI DOTYCZĄCE WYDARZEŃ DRUGIEJ WOJNY ŚWIATOWEJ Z POMNIKAMI POŚWIĘCONYMI STRATOM W WYNIKU ATAKÓW TERRORYSTYCZNYCH Z PRZEEOMU XX I XXI WIEKU}

Sztuka pomnikowa odnosząca się do wydarzeń dotyczących współczesnego świata opiera się na podobnych formułach artystycznych, jakie w ciągu ostatnich dekad wypracowały działania komemoratywne związane z pomnikiem postpamięci. Pod względem artystycznym pomniki poświęcone tragediom rozgrywającym się na kontynentach europejskim i północnoamerykańskim inspirują się rozwiązaniami zaproponowanymi przez artystów w celu przedstawienia wydarzeń drugiej wojny światowej. To, co zasadniczo różni pomniki poświęcone atakom terrorystycznym od obiektów stworzonych w nurcie postpamięci, to dystans czasowy pomiędzy zdarzeniem a fundacją nośnika pamięci jemu poświęconego. Pomniki odwołujące się do ataków terrorystycznych powstają w bardzo krótkim czasie po dramatycznych wydarzeniach. Proces upamiętnienia prowadzony jest pod wpływem silnej presji społecznej i wizualizuje się w przestrzeni publicznej od prostych form indywidualnych aktów oddawania spontanicznego hołdu do wielkoprzestrzennych założeń pomnikowych obejmujących znaczne areały miasta. Przebiega on zgodnie z charakterystyką współczesności dotyczącą narastania zainteresowania przeszłością. Zjawisko społecznego zainteresowania przeszłością nazywane memory boom ma wpływ również na działania architektoniczne ${ }^{10}$.

Wielkoprzestrzenność to jedna z ważniejszych cech współczesnego nośnika pamięci. Dziś do przeszłych wydarzeń nie odnoszą się tylko i wyłącznie punktowe instalacje artystyczne, ale również założenia pomnikowe ujmujące w przestrzennej kompozycji rozwiązania zaczerpnięte z rzeźby, architektury, urbanistyki i sztuki kształtowania krajobrazu. Adaptacja większych powierzchni do funkcji upamiętniania jest pokłosiem potrzeby wizualizacji traumy pozostałej po dwóch wojnach światowych. Parametry przestrzenne założeń upamiętniających bezpośrednio odnosiły się do skali dramatycznych doświadczeń społeczności. Powstające po wojnie realizacje założeń pomnikowych zainicjowały transformacje, które dokonały się później w sztuce pomnikowej ${ }^{11}$.

Ujęcie większego terenu w zakres upamiętniania podejmują również główne realizacje komemoratywne związane z uczczeniem ofiar ataków terrorystycznych, do których

10 M. Saryusz-Wolska, Wprowadzenie, [w:] Pamięć zbiorowa i kulturowa. Wspótczesna perspektywa niemiecka, red. M. Saryusz-Wolska, Kraków 2009, s. 7-38, Horyzonty Nowoczesności; S. Arnold-de Simine, Mediating memory in the museum: Trauma, empathy, nostalgia, London 2013.

11 I. Grzesiuk-Olszewska, Polska rzeźba pomnikowa...; K. Murawska-Muthesius, Oskar Hansen and the Auschwitz 'Countermemorial', 1958-59, „ARTMargins” 2002, [online:] http://www.artmargins.com/ index.php/featured-articles/311-oskar-hansen-and-the-auschwitz-qcountermemorialq-1958-59, 16 II 2017; Ł. Posłuszny, Przestrzenne formy upamiętniania Zagtady, Kraków 2014; G. Rytel, Czas zawarty w przestrzeni. Architektura wspótczesnych zatożeń upamiętniajacych, „Politeja” 2015, nr 35, s. $133-141$. 
doszło na terenie Stanów Zjednoczonych Ameryki. Strefą sacrum zostaje objęty duży obszar dotknięty zamachem. Powstałe w Oklahoma City w 2000 roku założenie pomnikowe obejmuje większość powierzchni zniszczonej pięć lat wcześniej na skutek wybuchu bomby podłożonej przed budynkiem federalnym imienia Alfreda P. Murraha, co stanowi blisko 1,3 hektara śródmiejskiej nieruchomości.

Wielkoprzestrzenną kompozycję uzyskał również pomnik poświęcony ofiarom największego ataku terrorystycznego w historii świata, do którego doszło w Nowym Jorku na Manhattanie 11 września 2001 roku. W niecały rok po wydarzeniu Lower Manhattan Development Corporation, agencja nadzorująca zagospodarowanie terenu po wyburzonym kompleksie WTC, zwanego Strefą Zero (ang. Ground Zero), ogłaszając międzynarodowy konkurs na formę upamiętnienia, wytypowała na bezpośrednie umiejscowienie pomnika kwartał, w którym znajdowały się bliźniacze wieże World Trade Center - bezpośredni cel ataku terrorystów. Procedura poddania określonej przestrzeni funkcji upamiętniającej przebiegała w trudnym kontekście, w którym należało wziąć pod uwagę opinię większości społeczeństwa o obowiązku objęcia tego terenu strefą sacrum oraz potrzebę ponownego podźwignięcia komercyjnego potencjału terenu zlokalizowanego wśród najdroższych na świecie nieruchomości.

Wielkoprzestrzenny charakter pomników sprzyja wprowadzeniu czasoprzestrzennej formuły upamiętniania, w przypadku której ważną rolę odgrywa aktywność odbiorcy w tym procesie ${ }^{12}$. W ramach realizacji upamiętniających powstają krajobrazy z tak ukształtowaną scenerią, by uwrażliwić użytkowników na odbiór przekazywanych komunikatów. W przypadku pomników poświęconych atakom terrorystycznym zniszczone kwartały miasta zostają przeobrażone w przestrzenną kompozycję symbolicznych elementów, motywującą do wędrówki w całkiem nieodległą przeszłość.

Zaprojektowany przez Butzer Design Partnership Oklahoma City National Memorial to założenie pomnikowe o estetyce bliskiej parkowi miejskiemu. Głównymi akcentami tej przestrzeni są: przetrwałe wybuch bombowy drzewo rosnące niegdyś przed zniszczonym budynkiem, monumentalne Bramy Czasu (ang. The Gates of Time) ujmujące w metaforyczne ramy czas pomiędzy godzinami 9.01 i 9.03, znajdujący się pomiędzy nimi Lustrzany Staw (ang. Reflecting Pool), sto sześćdziesiąt osiem pustych krzeseł z wygrawerowanymi nazwiskami osób, które zginęły w ataku oraz Ściana Ocalałych (ang. Survivors' Wall) będąca jedynym zachowanym fragmentem konstrukcji budynku, przy którym zdetonowana została bomba. Wszystkie te elementy tworzą przestrzeń wyciętą metaforycznie z dynamiki otaczającej metropolii.

Podobną konwencję parku miejskiego przyjęto również dla nowojorskiego kwartału z ruinami po World Trade Center. Do realizacji w 2004 roku został skierowany zwycięski projekt w konkursie architektonicznym autorstwa architektów Michaela Arada i Petera Walkera. Koncepcja zatytułowana „Odzwierciedlając nieobecność” (ang. Reflecting Absence) zakładała utworzenie parku z dwoma basenami usytuowanymi w miejscu dawnej lokalizacji fundamentów bliźniaczych wież. Otwarte w 2011 roku na bazie tych założeń Miejsce Pamięci 9/11 (ang. 9/11 Memorial) stanowi dziś przestrzeń pomagającą

12 I. Grzesiuk-Olszewska, Polska rzeźba pomnikowa... 
się wyciszyć, pomimo sąsiedztwa gwarnego Manhattanu. Sprzyja temu park obsadzony dwoma charakterystycznymi dla flory amerykańskiej gatunkami drzew: dębem dwubarwnym i ambrowcem amerykańskim oraz szmer wody wydobywającej się z dwóch zbiorników stworzonych na wzór wodospadów. Miejsce zaznaczone tragedią zyskuje tym samym złagodzoną szatę krajobrazową sprzyjającą powstaniu refleksyjnej atmosfery. W ten sposób dochodzi do rewitalizacji traumatycznej przestrzeni publicznej.

W pomnikach postpamięci dotyczących przede wszystkim tematyki Holocaustu architektura przyjmuje estetykę prowadzącą do skojarzeń z metaforyczną raną znaczącą przestrzeń miejską. Taka „skaza” została wprowadzona m.in. w Berlinie przy okazji kreacji Pomnika Pomordowanych Żydów Europy. W przypadku założeń pomnikowych poświęconych atakom terrorystycznym piękno parku miejskiego jest wykorzystywane, by stworzyć miejsce sprzyjające kontemplacji oraz dające wiarę w odnowę. Obie wymienione powyżej amerykańskie koncepcje charakteryzuje architektura odbierana przez użytkowników jako przestrzeń symbolicznie odwołująca się do pokoju, dobrostanu oraz nadziei.

Analogiczny cel przyświeca również i innym pomnikom poświęconym skutkom zamachów terrorystycznych. Kontemplacji sprzyja forma pomnika zadedykowanego ofiarom ataków terrorystycznych dokonanych 7 lipca 2005 roku w Londynie. Usytuowane w 2009 roku pośród zieleni Hyde Parku miejsce pamięci autorstwa studia Carmody Groarke ma formę pięćdziesięciu dwóch stalowych filarów reprezentujących każde z utraconych w masakrze istnień. Metaforyczne stele, opatrzone inskrypcją zawierającą datę, dokładny czas i miejsce śmierci każdej z ofiar, ułożono na planie niesymetrycznego wzoru opartego na czterech grupach, z których każda reprezentuje jedną z lokalizacji podłożonych cztery lata wcześniej bomb. Taka formuła skłania odwiedzających park do spaceru wśród steli i tym samym włączenia się w proces upamiętnienia jednej z ważniejszych tragedii, jakie dotknęly współczesny Londyn.

Jak silna jest potrzeba wprowadzenia elementu wyciszenia i nadziei na odnowę do procesu upamiętniania skutków ataków terrorystycznych, świadczy historia uczczenia ofiar masakry dokonanej 22 lipca 2011 roku na norweskiej wyspie Utøya. Pierwsza koncepcja zaproponowana przez szwedzkiego artystę Jonasa Dahlberga zakładała silną interwencję w naturalny krajobraz miejsca, w którym doszło do tragedii. Projekt „Rana pamięci” (ang. Memory Wound) zakładał odseparowanie części półwyspu Sørbraten podłużnym kanałem utworzonym z siłą chirurgicznego cięcia. Naznaczony traumą norweskiego społeczeństwa krajobraz miał uzyskać wizualizację otwartej rany. Jednakże odważna koncepcja, pomimo przychylności krytyków oraz przyznanych nagród (m.in. Innovation By Design Awards 2014), nie została zrealizowana. Zarzucono jej przede wszystkim zbyt silną ingerencję w środowisko przyrodnicze. Naturalny krajobraz miał zostać trwale zdewastowany, by „stanowić symbol ogromnej, nieustannie odczuwanej utraty" ${ }^{13}$. Ta koncepcja w większym stopniu była rozwiązaniem potęgującym poczucie zniszczenia niż niosącym ukojenie.

13 M. Praczyk, Rana w Ziemi. O paradoksach Utøya „Memory Wound” i kondycji antropocenicznej, [w:] Pomniki w epoce antropocenu, red. M. Praczyk, Poznań 2017, s. 149. 
Do procesu odnowy odnosi się kolejna propozycja formy upamiętnienia ofiar masakry zaproponowana przez artystów z pracowni 3RW Arkitekter. Nawiązali oni w swojej koncepcji przestrzennej do figury metaforycznej związanej ze zjawiskiem formowania się leśnej polany powstającej po obumarciu drzew. Projektanci utworzyli w jednym z leśnych zakątków wnętrze krajobrazowe na wzór tych, które powstają, by ludzie mogli spędzać wspólnie czas przy ognisku. Ten krąg wyróżnia jednak zawieszony ponad nim, pośród drzew, stalowy pierścień, na którego powierzchni wycięte zostały nazwiska ofiar masakry. Poprzez swoją lokalizację i uksztattowanie „Przecinka” (ang. The Clearing) otwiera się na naturalny krajobraz, który sprzyja odnowie i rekonwalescencji ludzi bezpośrednio dotkniętych skutkami mającej tu miejsce tragedii.

Innym zabiegiem artystycznym, który zastosowany w sztuce pomnikowej sprzyja wykreowaniu przestrzeni do kontemplacji, jest nawiązanie do pustki - figury metaforycznej odnoszącej się do poczucia straty, osamotnienia i niepewności. Wizualizacja pustki w sztuce pomnikowej tworzonej przez pokolenie postpamięci odnosi się głównie do motywu unicestwienia społeczności żydowskiej i związanej z nią kultury przez nazistowski reżim ${ }^{14}$. Motywem tym inspirowali się artyści projektujący obiekty komemoratywne dedykowane berlińskiemu krajobrazowi, m.in. Christian Boltanski, tworząc memorial "Zgubiony dom” (ang. The Missing House) z 1990 roku, Micha Ullman przy kreacji instalacji komemoratywnej „Pusta biblioteka” (ang. The Empty Library) z 1995 roku oraz Daniel Libeskind podczas projektowania rozbudowy Muzeum Żydowskiego, budynku otwartego w 2002 roku.

Do budzącego się poczucia wszechogarniającej pustki przy okazji upamiętnienia strat spowodowanych atakami terrorystycznymi odwołuje się rzeźba „Puste niebo” (ang. Empty Sky) zrealizowana w 2011 roku w Jersey City, według projektu Frederica Schwartza i Jessiki Jamroz. Na przeciwległym do Manhattanu brzegu powstały dwie stalowe ściany kadrujące widok na dzielnicę z panoramy, z której zniknęły bliźniacze wieże World Trade Center. Głównym zamierzeniem projektu jest zaakcentowanie okaleczonego krajobrazu nowojorskiego i wyeksponowanie po latach inwestycji budowlanych, które zastąpią architekturę sprzed zamachu.

Intencja symbolicznego nawiązania do pustki towarzyszyła również autorom pomnika na madryckiej stacji kolejowej Atocha poświęconego stu dziewięćdziesięciu jeden ofiarom ataku terrorystycznego, który miał miejsce 11 marca 2004 roku. Pracownia FAM Arquitectura y Urbanismo zaproponowała monument składający się z dwóch części ściśle ze sobą powiązanych: szklanej kopuły wyróżniającej się w przestrzeni miasta oraz znajdującego się pod nią pomieszczenia dostępnego bezpośrednio z głównego holu stacji. Z podziemnej komory można obserwować wnętrze szklanej kopuły, na której powierzchnię naniesiono teksty komunikatów i setek wiadomości pozostawionych na stacji przez żałobników bezpośrednio po ataku. Przystanek we wnętrzu nacechowanym ciszą i niebieskim światłem stanowi punkt przejściowy w codziennych wędrówkach setek mieszkańców Madrytu.

Silne oddziaływanie wydarzenia historycznego na pamięć wpływa na rozszerzenie

14 A. Huyssen, Berlińskie pustki, przeł. J. Mostowska, [w:] Pamięć zbiorowa i kulturowa..., s. 432-457. 
lokalizacji pomników poza miejsce bezpośrednio z nim związane. Obiekty realizowanie w nurcie postpamięci powstają w szerokim zakresie umiejscowienia przestrzennego. Dotyczy to w szczególności upamiętniania Zagłady - obiekty poświęcone pamięci o ofiarach nazistowskiej eksterminacji na tle rasowym powstają dziś poza kontynentem europejskim, który jest miejscem bezpośrednio związanym z dramatem. Proces przepracowywania powojennej traumy przez kolejne pokolenia sprzyja multiplikacji wizualizacji pamięci w formie pomników. Liczne instalacje komemoratywne poświęcone tej tematyce w postaci rzeźb i obiektów muzealnych powstają w krajach Ameryki Południowej i Północnej oraz w Australii.

Większość pomników poświęconych stratom powstałym w wyniku ataku terrorystycznego stawiana jest wyłącznie w mieście, w którym bezpośrednio doszło do tragedii. Znaczącym wyjątkiem, który siłą globalnego oddziaływania wymusił potrzebę transgranicznego upamiętnienia, jest atak terrorystyczny z 11 września 2001 roku. Realizacje upamiętniające nowojorską katastrofę powstają w licznych reprezentacjach nie tylko w Stanach Zjednoczonych, ale ustanawiane są niejednokrotnie w miejscach odległych od północnoamerykańskiego kontynentu. I tak w 2005 roku w Padwie na nabrzeżu rzeki Bacchiglione powstał monument nazwany „Pamięć i światło” (wł. Memoria e Luce). Autor instalacji Daniel Libeskind w kompozycji przestrzennej nawiązującej do otwartej księgi wykorzystał fragment oryginalnej stalowej belki z ruin nowojorskiego World Trade Center, która została podarowana przez Stany Zjednoczone włoskiemu regionowi Wenecja Euganejska (il. 1, 2). Element budowlany zyskał w tym przypadku status relikwii, która jest przekazywana w procesach dyplomatycznych pomiędzy różnymi państwami.

Ujęcie elementu z fizycznie zbudowanego krajobrazu z czasów wydarzenia poddanego upamiętnianiu jest kolejną cechą, która została przejęta z pomników kreowanych w charakterystyce postpamięci do realizacji komemoratywnych obiektów tworzonych w celu upamiętnienia ofiar ataków terrorystycznych. W nośnikach pamięci dotyczących wydarzeń z drugiej wojny światowej każdy przetrwały artefakt związany bezpośrednio z przeszłością jest traktowany jak element poddany sakralizacji. Podobny mechanizm został zastosowany jeszcze w kilku realizacjach upamiętniających powstałych poza bezpośrednim terenem ruin World Trade Center. Budowlanym pozostałościom, które przetrwały atak, nadaje się status relikwii. Stalowe fragmenty konstrukcji bliźniaczych wież stanowią element instalacji rzeźbiarskich poświęconych zamachowi z 11 września 2001 roku zlokalizowanych poza terenem Manhattanu.

Szczególną rolę w tym kontekście odgrywa drzewo - świadek, roślina, która cudem przetrwała niszczycielską siłę ataku terrorystycznego. Drzewa rosnące w przestrzeni, w której miało miejsce ważne wydarzenie z przeszłości poddawane są zabiegowi antropomorfizacji. Nadane zostaje im miano świadka historii i taką rolę odgrywają w symbolice założeń upamiętniających. W zniszczonej w wyniku wybuchu tkance urbanistycznej drzewa stają się symbolem żałoby, życiowej odporności, przetrwania i odrodzenia.

Przykładem tego typu ujęcia postkatastroficznego krajobrazu jest historia amerykańskiego wiązu rosnącego przy budynku federalnym imienia Alfreda P. Murraha w Oklahoma City. Znaczące uszkodzenia będące efektem wybuchu bomby, który miał 
tu miejsce 19 kwietnia 1995 roku, i późniejszych działań związanych z akcją ratowniczą nie zapowiadały rehabilitacji drzewa, która nastąpiła w niecały rok po tragedii. Drzewo zostało otoczone opieką mieszkańców, zyskując przydomek „Ocalonego” (ang. The Survivor Tree) i od 2000 roku stanowi ważny element kompozycji Oklahoma City National Memorial.

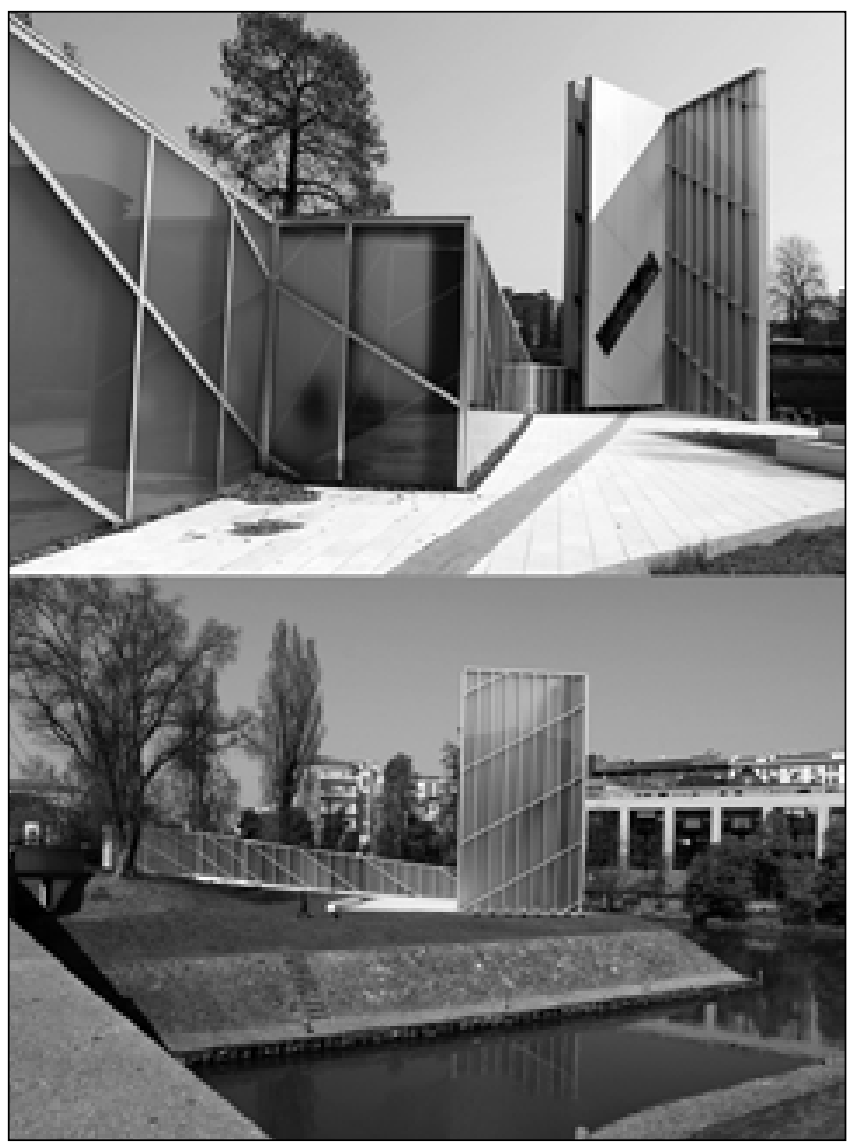

1-2. Pomnik Memoria e Luce w Padwie. Fot. A. Gębczyńska-Janowicz, 2018

Podobna rola przypadła nowojorskiej gruszy rosnącej w kwartale World Trade Center zniszczonym w wyniku zamachu terrorystycznego w 2001 roku. Połamane drzewo, ze znaczącymi uszkodzeniami w koronie i korzeniach odcinało się w opustoszałym krajobrazie ruin bliźniaczych wież. Podczas prac porządkujących kwartał po katastrofie drzewo zostało usunięte i umieszczone pod opieką nowojorskiego departamentu do spraw parków i rekreacji. Po trwających kilka lat zabiegach rehabilitacyjnych drzewo zostało przywrócone do przestrzeni publicznej jako żywy pomnik, stając się w 2010 roku symbolicznym dodatkiem do kompozycji założenia pomnikowego 9/11 Memorial. W jego sąsiedztwie zasadzono kilkadziesiąt drzew z gatunków 
charakterystycznych dla amerykańskiej flory. Razem symbolizują społeczny rozwój postępujący pomimo silnej traumy tkwiącej w środowisku mieszkańców Nowego Jorku ${ }^{15}$.

Realizacje upamiętniające ofiary ataku terrorystycznego odwołują się niejednokrotnie do szerszego zakresu pojęć powiązanych z zamachem. Instalacje motywują użytkowników przestrzeni publicznej, by przy okazji procesu upamiętniania poddali się szerszej refleksji dotyczącej współczesnej kondycji społecznej. Przykładem próby takiego oddziaływania na społeczeństwo poprzez sztukę w przestrzeni publicznej jest monument „Przemieszczenia Pamięci - Miejsce Pamięci 9/11 w Arizonie” (ang. Moving Memories - The Arizona 9/11 Memorial) usytuowany w 2006 roku w Phoenix. Zaprojektowana przez Jones Studio i coLAB Studio instalacja architektoniczno-rzeźbiarska organizuje przestrzeń, w której przechodzień może poświęcić chwilę na przemyślenia dotyczące wpływu przekształceń pamięci na współczesną kulturę. Podane w tym miejscu inskrypcje odwołują się do takich zjawisk społecznych interpretowanych powszechnie jako pokłosie ataków terrorystycznych, jak: popularyzacja ksenofobii, rosnąca krytyka dalszego angażowania się kraju w konflikty międzynarodowe lub rosnące poczucie zagrożenia $\mathrm{w}$ przestrzeni publicznej. Tego typu realizacje komemoratywne wykraczają funkcjonowaniem dalece poza proces upamiętniania oraz oddania czci i hołdu. Kontynuują formalnie założenia nurtu sztuki pomnikowej, której realizacje pojawiły się w niemieckich miastach w latach 80 . XX wieku jako próby kreowania sztuki publicznej poświęconej przeszłości w opozycji do tradycyjnego monumentalizmu, charakterystycznego dla totalitarnych ideologii. Nowy wówczas kierunek artystyczny nazwany jest dziś za Jamesem E. Youngiem kontrpamięcią (ang. counter-memory). Bazując na ideach sztuki konceptualnej i minimal artu, promował on śmiałe podejście do upamiętniania jako procesu, który poprzez wywołanie kontrowersji otwiera pole do dysputy na temat oddziaływania przeszłości na współczesne społeczeństwo.

Powszechne zainteresowanie poszerzonymi kontekstami dotyczącymi przeszłości sprawia, że nośnik pamięci pełniący tylko i wyłącznie funkcje upamiętniające staje się artefaktem niespełniającym potrzeb współczesnego społeczeństwa. Musi on sprostać wymaganiom dotyczącym wykreowania opakowania dla archiwizacji informacji przybliżających różny bagaż doświadczeń wynikających z konkretnego wydarzenia z przeszłości. Bill Niven interpretuje część współczesnych realizacji muzealnych eksponujących historię drugiej wojny światowej jako kolejną generację pomników na drodze postępującej redefinicji wizualizacji pamięci ${ }^{16}$. „Kombipomniki” (ang. combimemorials) są formułą fizycznych nośników narracji o przeszłości najbliżzzej integracji architektury ze sztuką pomnikową. Powstają jako kolejna ewolucja następująca po trendach w sztuce współczesnej reprezentujących idee kontrmonumentalny (ang.

15 Ch. Heath-Kelly, Survivor Trees and memorial groves: Vegetal commemoration of victims of terrorism in Europe and the United States, „Political Geography” 2018, nr 64, s. 63-72.

16 B. Niven, From Countermonument to Combimemorial: Developments in German Memorialization, „Journal of War and Culture Studies” 2013, nr 1, s. 75-91. 
counter-monumental) oraz kontrpomnikowy (ang. counter-memorial), związane ze środkami artystycznymi będącymi w opozycji do monumentalności i tradycyjnej formuly pomnika ${ }^{17}$.

Kirk Savage uważa, że popularność muzeów historycznych doprowadziła do zjawiska ujmowania w założenia pomnikowe upamiętniające ataki terrorystyczne obiektów ekspozycyjnych, które dokumentują i personalizują ludzkie cierpienie ${ }^{18}$. Tego typu instytucja formowana była w Oklahoma City, zanim w 2000 roku odsłonięto założenie pomnikowe. W Nowym Jorku w kwartale po zburzonych wieżach WTC najpierw odsłonięto w 2011 roku pomnik, zaś trzy lata później nastąpiło otwarcie muzeum (9/11 Memorial Museum). Jest w nim prezentowana historia ataków terrorystycznych z perspektywy samego dnia, w którym dramat się rozegrał, ale również wydarzeń go poprzedzających, jak i przedstawiających świat po ataku. Obiekt dodatkowo stanowi siedzibę instytucji zajmującej się badaniem skutków wydarzeń z 11 września 2001 roku i dokumentującej ich wpływ na dalsze losy amerykańskiego społeczeństwa.

\section{PODSUMOWANIE}

Postpamięć wpłynęła na tyle silnie na sztukę pomnikową, że formuły organizacji miejsc traumatycznych z przeszłości odległej czasowo stosowane są przy wypełnianiu społecznej potrzeby upamiętnienia wydarzeń dużo bardziej aktualnych. Rozwiązania formalne wypracowane dla interpretacji wydarzeń historycznych związanych z drugą wojną światową przyjęły się jako kanon współczesnych form upamiętniających realizujących potrzeby świeżej traumy społecznej ${ }^{19}$. Pomniki ataków terrorystycznych są przejawem nie tyle pamięci zbiorowej, ile potrzeby wizualizacji żałoby i próbą sprostania codzienności nacechowanej poczuciem zagrożenia. Stanowią stały element krajobrazu miejskiego, pomimo że ich obecność przypomina o nieustającym zagrożeniu wystąpienia kolejnego zamachu.

Charakterystyczna dla pomnika postpamięci koncepcja wielkoprzestrzennej formy upamiętnienia umożliwia rewitalizację zrujnowanej w wyniku zamachu tkanki urbanistycznej. Założenia pomnikowe przyjmują postać parku miejskiego, by atmosferą dobrostanu prowadzić do powolnego procesu odnowy społecznych interakcji. Czasoprzestrzenne kompozycje sprzyjają aktywizacji użytkowników przestrzeni publicznych w kierunku refleksji na temat szerokiego pola kontekstów powiązanych z zamachem, zjawisk występujących przed atakiem terrorystów i tych będących jego następstwem. Potrzeba rozszerzenia funkcji upamiętniającej o strategie edukacyjne i prospołeczne prowadzi do realizacji w bezpośrednim sąsiedztwie założeń pomnikowych obiektów

17 J.E. Young, At Memory's Edge: After-images of the Holocaust in Contemporary Art and Architecture, London 2000.

18 K. Savage, Monument Wars. Washington, D.C. The National Mall, and the Transformation of the Memorial Landscape, Berkeley-Los Angeles-London 2009, s. 288.

19 Więcej na ten temat w artykule: A. Awtuch, Narracje o świeżej traumie - upamiętnianie ataków terrorystycznych w krajobrazie codziennym miast, w niniejszym tomie. 
ekspozycyjnych będących jednocześnie siedzibą instytucji zajmujących się analizami wpływu skutków zamachu na społeczną kondycję. Działania te wielokrotnie przekraczają aktywności tradycyjnie związane bezpośrednio ze wzniesieniem pomnika. Wytwarzają struktury pomocne w wywoływaniu pozytywnych interakcji społecznych mogących przywrócić poczucie bezpieczeństwa w przestrzeni miejskiej.

\section{BIBLIOGRAFIA}

Arnold-de Simine S., Mediating memory in the museum: Trauma, empathy, nostalgia, London 2013, https://doi.org/10.1057/9781137352644.

Gębczyńska-Janowicz A., Polskie zatożenia pomnikowe. Rola architektury w tworzeniu miejsc pamięci od potowy XX wieku, Warszawa 2010.

Gębczyńska-Janowicz A., Wspótczesne miejskie krajobrazy pamięci o II wojnie światowej na przyktadzie Warszawy i Berlina, „Borussia. Kultura. Historia. Literatura” 2011, nr 50.

Golka M., Imiona wielokulturowości, Warszawa 2010.

Grzesiuk-Olszewska I., Polska rzeźba pomnikowa w latach 1945-1995, Warszawa 1995.

Heath-Kelly Ch., Survivor Trees and memorial groves: Vegetal commemoration of victims of terrorism in Europe and the United States, „Political Geography” 2018, nr 64, https://doi.org/10.1016/j.polgeo.2018.03.003.

Hirsch M., Family Frames: Photography, Narrative, and Postmemory, Cambridge 1997.

Huyssen A., Berlinskie pustki, przeł. J. Mostowska, [w:] Pamięć zbiorowa i kulturowa. Wspótczesna perspektywa niemiecka, red. M. Saryusz-Wolska, Kraków 2009, Horyzonty Nowoczesności.

Huyssen A., Present pasts: Urban palimpsests and the politics of memory, Stanford 2003.

Jasiński A., Architektura w czasach terroryzmu: Miasto - przestrzeń publiczna - budynek, Warszawa 2013.

Mach A., Poetyka postpamięci i etyka świadkowania w badaniach Marianne Hirsch, „Humanistyka XXI Wieku" 2010, nr 1, s. 105-116.

Murawska-Muthesius K., Oskar Hansen and the Auschwitz 'Countermemorial', 1958-59, „ARTMargins" 2002, [online:] http://www.artmargins.com/index.php/featured-articles/311oskar-hansen-and-the-auschwitz-qcountermemorialq-1958-59, 16 II 2017.

Niven B., From Countermonument to Combimemorial: Developments in German Memorialization, „Journal of War and Culture Studies" 2013, nr 1, https://doi.org/10.1179/17526272 12Z.0000000006.

Posłuszny E., Przestrzenne formy upamiętniania Zagtady, Kraków 2014.

Praczyk M., Rana w Ziemi. O paradoksach Utoya „Memory Wound" i kondycji antropocenicznej, [w:] Pomniki w epoce antropocenu, red. M. Praczyk, Poznań 2017.

Rytel G., Czas zawarty w przestrzeni. Architektura wspótczesnych zatożeń upamiętniajacych, „Politeja" 2015, nr 35, https://doi.org/10.12797/Politeja.12.2015.35.10.

Saryusz-Wolska M., Wprowadzenie, [w:] Pamięćzbiorowa i kulturowa. Wspótczesna perspektywa niemiecka, red. M. Saryusz-Wolska, Kraków 2009, Horyzonty Nowoczesności.

Savage K., Monument Wars. Washington, D.C. The National Mall, and the Transformation of the Memorial Landscape, Berkeley-Los Angeles-London 2009. 
Young J.E., At Memory's Edge: After-images of the Holocaust in Contemporary Art and Architecture, London 2000.

Young J.E., Memory and Counter-Memory, „Harvard Design Magazine” 1999, nr 9.

Dr inż. arch. Agnieszka GĘBCZYŃSKA-JANOWICZ - jest adiunktem na Wydziale Architektury Politechniki Gdańskiej. Ukończyła studia na kierunku architektura i urbanistyka na Wydziale Architektury Politechniki Gdańskiej. Na tejże uczelni obroniła w 2010 roku pracę doktorską pt. Rola architektury $w$ tworzeniu miejsc pamięci od potowy XX wieku do wspótczesności. W swojej działalności badawczej kontynuuje temat współczesnych form wizualizacji pamięci zbiorowej: Wspótczesne krajobrazy pamięci, „Architektura Krajobrazu” (2011); Bezimienne nekropolie - udziat gdańskich artystów w procesie organizowania zatożeń pomnikowych na terenach masowych eksterminacji z czasów II wojny światowej, [w:] Nekropolie Pomorza (2011); Wspótczesne miejskie krajobrazy pamięci o II wojnie światowej na przyktadzie Warszawy i Berlina, „Borussia. Kultura. Historia. Literatura" (2011); Przestrzenne nośniki polskiej pamięci zbiorowej po 1989 roku, [w:] Krajobraz kulturowy wolnej Polski (2013); Franciszek Duszeńko. Postać monumentalna, [w:] Franciszek Duszeńko (2014) oraz monografia pt. Architektura na terenach bytych nazistowskich obozów koncentracyjnych. Funkcjonalna zmienność upamiętniania (2019). Brała udział w kilkunastu konferencjach ogólnopolskich i międzynarodowych dotyczących specyfiki pamięci zbiorowej w ujęciu interdyscyplinarnym. Efekty badań popularyzowała prezentacjami na zaproszenie uczelni w Gdańsku, Krakowie, Sofii, Ljubljanie i Hamburgu.

Dr inż. arch. Anna AWTUCH - psycholog i architekt, adiunkt na Wydziale Architektury Politechniki Gdańskiej. Jej zainteresowania badawcze to: psychologia architektury, percepcja przestrzeni i miejsca, podejście kontekstualne w architekturze. Obecnie zajmuje się badaniem czynników wzmacniających wspierającą rolę architektury w kształtowaniu dobrostanu psychofizycznego człowieka. 